\title{
War, America, and Modernity: Anscombe's revival of the Combination Factory
}

Christine McCarthy, School of Architecture, Victoria University, Wellington

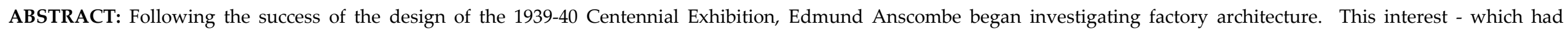

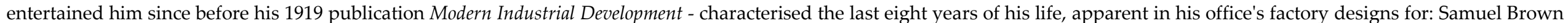

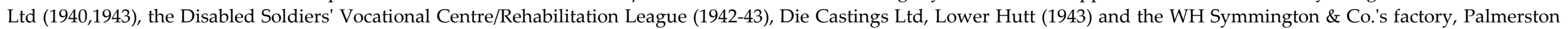
North (1948). This paper examines this work in relation to his visit to America in 1940 and his proposal for a combined factory on Aotea Quay (1943).

\section{Introduction}

I don't think anyone has ever accused Edmund Anscombe of being a Modernist. Best known for his Art Deco and exhibition designs (culminating in his 1939-40 Centennial Exhibition), his architectural design has been seen to be dominated by what Modernist Bill Toomath has described as "forbidden fruit": streamlining and the moderne. ${ }^{1}$ While Toomath's fascination with Art Deco became somewhat suppressed and only recently discussed in public, Anscombe was unashamedly immersed in it. While Anscombe and Art Deco have historiographically sung from the same songsheet, Anscombe and Modernism are what one might describe as two things that don't belong in the same sentence. This paper though will argue that Anscombe's relationship to Modernism is more complex

${ }^{1}$ Toomath "Hidden Persuaders, Forbidden Fruit" pp 6266. than this, and that this co-incidence is particular to, and facilitated through, his 1940s work. It insinuates a Modern, rather than moderne, side to Anscombe, as one more of his many chameleon endeavours, and argues this via his architectural upbringing in early twentieth-century America, his commitments to a scientific approach to architecture, progressive building technology, architecture as a politically effective vehicle, and (only finally), via a Modernist aesthetic. This aspect of Anscombe's work is amplified in his factory design and its influences from American and from wartime conditions.

\section{Factory Architecture and Modernism}

It is old news to state that Modernism had a fascination with functionalism, rationalism and mass-production, mixed with a dash of Socialism. The machine asethetic of Gropius and the Bauhaus, Le Corbusier's reconceptionalisation of the house as "a machine-for-living," and Frank Lloyd Wright's mantra that "Form follows Function" are all well known. Mary McLeod has argued in 1983 that Le Corbusier was associated with "a general ideological position current in postwar France that was predicated on American models of industrial rationalization and managerial reform,"2 referencing his "applications of mass-production techniques to housing,"3 "his pursuit of prefabricated low-cost housing,"4 and the modelling of "housing production on airplane and automobile manufacture." 5 Likewise Reyner Banham's 1986 A Concrete Atlantis argues "connections between North American industrial building and the classic modernist architecture of the International Style in Europe."6

\footnotetext{
${ }^{2}$ McLeod "'Architecture or Revolution"'" p 133.

3 McLeod "'"Architecture or Revolution"'" p 135.

${ }^{4}$ McLeod "'Architecture or Revolution"'" p 135.

${ }^{5}$ McLeod "'Architecture or Revolution"'" p 136.

${ }^{6}$ Banham A Concrete Atlantis
} 
A closer reading of the history of factory architecture shifts the usual focus on massproduction and the notion of the machine (which frequently constructs the relationship between Modernism and the industrial), to the factory building itself as a significant contemporary to Modernist endeavours. Modernist architecture was not so much like industrial architecture, it was factory architecture in a stunningly comprehensive way. Almost every factory architecture innovation, from the late nineteenth-century through to the second decade of the twentieth-century, was co-opted by Modernists from about the 1920s.

\section{Factory Architecture}

In the concluding years of the nineteenth century, the façade of a factory was typically distinct from the work-house shed. It was often neo-classical or Palladian in sentiment, and has been described as "dressing" the factory shed. ${ }^{7}$ Anscombe's early factory work such as the 1909 Thomas Scurr carriage factory, epitomises this fashion, which gradually changed, both as factories got larger (and were unable to sustain Palladian

\footnotetext{
${ }^{7}$ Darley Factory p 21
}

proportions), ${ }^{8}$ and as building technology shifted the function of weight-bearing from walls to a structural grid. Factory theorists, such as architect Albert Kahn's younger brother Moritz, advocated for a new factory aesthetic in the following way:

a factory should [not] appear to be what it is not Factories should look like what they are - factories and nothing else. For effect they should rely on the straightforward expression of their structure, on mass, and on the skilful disposition of their parts, the whole being co-ordinated into a well-designed architectura scheme. To attempt to make an indifferent building look presentable by applying ornament to it with a lavish hand is bound to prove a failure. The right method is suitably to arrange the main parts, to study the proportions of solids and voids, to emphasise structural lines by relief or colour - in a word, to articulate the structure. ${ }^{9}$

Beauty in the factory shifted from a twodimensional applied image into structural integrity, as the expression of architectural function was exhaulted. Reinforced concrete was embraced for a multiple of reasons. It enabled fewer columns, reduced machine vibrations, it was stronger than timber, and fire proof, meaning lower insurance

${ }^{8}$ Tann The Development of the Factory p 157.

${ }^{9}$ Kahn The Design and Construction of Industrial Buildings pp 47-48. premiums. ${ }^{10}$ It enabled the structural grid to be effected and hence the development of the Model, or Daylight, Factory which was dependent on shifting the weight-bearing responsibility of walls to elsewhere. Windows morphed into window-walls.

Functionalism, inflicted on the factory by Capitalism, ${ }^{11}$ radically changed the interior of the building. Innovations in mass-production dictated that a notion of efficiency moved the idea of the factory and workshop into that of the machine, as Biggs notes "Factory layout and design become a major focus of industrial engineering ... the machine embodied rationality, a machine was predictable, controllable, nonidiosyncratic, easy to routinize and systemize."12 The machine (as conveyor belts and travelling cranes) determined both circulation routes and rates: "the speed of production was almost completely determined by the speed of the handling system rather than by the speed at which workers wanted to work,"13 achieving

${ }^{10}$ Biggs The Rational Factory pp 52-53.

11 "By 1910 factory architecture had assume new significance as fixed capital ... [requiring] a trained professional to design it." Biggs The Rational Factory p 48.

${ }^{12}$ Biggs The Rational Factory pp 46-47.

${ }^{13}$ Biggs The Rational Factory p 50. 
factory owners' desires for predictable work flow to enable efficient ordering of materials and to maximise productivity by keeping "the machine tools operating as continuously as possible."14 Efficiency and the elimination of cost-generating waste (both material and human labour) was focussed on at every level. Biggs noted that workers were re-concieved as "animate machines;"15 the factory building itself as "the master machine"16 and part of industrial technology, rather than a passive structure.

Open planning was sought after, again to achieve worker productivity. Eliminating hidden corners, characteristic of the traditional L, E and $\mathrm{H}$-shaped plans, enabled better visibility and hence more effective supervision of employees. ${ }^{17}$ A minimum of passageways reduced "unproductive travel"18 and carriage of goods and materials. Flexibility was also key, Darley noting that while being "the objective of much twentiethcentury architecture ... [flexibility was] nowhere more so than in the workplace.

\footnotetext{
${ }^{14}$ Biggs The Rational Factory p 79.

${ }^{15}$ Biggs The Rational Factory p 51.

${ }^{16}$ Biggs The Rational Factory p 49.

${ }^{17}$ Biggs The Rational Factory p 51.

${ }^{18}$ Biggs The Rational Factory p 51.
}

Changing working practices were continually affecting the factory." 19

Productivity relied on human efficiency. FW Taylor, and later Frank and Lillian Gilbreth, conducted motion studies with the aim of isolating the most efficient movements to be used by factory-workers, ${ }^{20}$ and "[i]n the new system of constantly repeated routine movements, workers' movements began to merge with those of the machine."21 But from such an emphasis on fulfilling the efficiency potential of human productivity emerged interests in employee welfare, and scientific evaluation of the optimal work conditions for human productivity: lighting, heating, ventilation and recreation were byproducts. Natural light was prioritised requiring "innovations in building and window design."22 Factory windows were enlarged until walls became window-walls and the Daylight Factory emerged. New functions such as dining rooms, rest rooms, libraries, theatres, auditoria, ballrooms, dance halls, clubrooms, gymnasiums, pool tables, swimming pools, bowling alleys, ball fields,

\footnotetext{
${ }^{19}$ Darley Factory p 82.

${ }^{20}$ Biggs The Rational Factory pp 62-63.

${ }^{21}$ Biggs The Rational Factory p 121.

${ }^{22}$ Biggs The Rational Factory p 57.
}

gardens, picnic areas, worker housing, and schools became associated with factory architecture. $^{23}$ Modernism's documented interest in health and recreation: fresh air, good ventilation and sunshine ${ }^{24}$ is equally, if not more so, apparent here. It was such thinking about factory design, that, rather than obviously impacting on his architecture, prompted Edmund Anscombe, in 1919, to write and publish a pamphlet titled Modern Industrial Development advancing contemporary factory thinking and to support his aim of building "Combination Factories."25

\section{Edmund Anscombe's Architecture}

Anscombe "studied" architecture in American from 1901-6. No one really knows what "studied" in this context really means. He worked as a carpenter in San Francisco and Saint Louis for three years (from 1901-c1904), and as a draughtsperson in New York for two, working in the offices of FJ Nisbit, McKim, Mead \& White, and Raymond F Almirall. ${ }^{26}$

\footnotetext{
${ }^{23}$ Biggs The Rational Factory pp 66-69.

${ }^{24}$ McLeod "Le Corbusier, the New Woman, and Domestic Reform" unpublished.

${ }^{25}$ Anscombe also uses the terms: Combined factory,

Terminal Factory and Business Incubator to describe his scheme.

${ }^{26}$ McCarthy "The Making of an Architect" pp 63-64,68.
} 
Anscombe always considered his architectural practice to be progressive and modern, though aesthetically his prolific competence at executing varying architectural styles makes an argument that he was a Modernist difficult, if not impossible, to sustain. Eggener though advocates for a re-thinking of what being modern meant from an early twentiethcentury American perspective. He asserts that:

Architects in the United States ... were expected to offer up a measure of continuity and stability in a country where change was a pervasive fact of daily life. European avant-gardists may have extolled machines in obscure manifestos, but Americans mass-produced and mass-consumed them. So the new architecture did not need to look entirely modern to be modern. It was modern, said a writer [Harbeson] in Pencil Points in 1930, by being, "quite simply, the architecture of today, the architecture which attempts to solve the problems resulting from modern social conditions, by modern methods of construction, and using the materials and resources we can now command."27

It is in this sense that I suspect Anscombe consistently practised his modernity.

A second strain was interwoven with this less

${ }^{27}$ Eggener "Nationalism, Internationalism and the

"Naturalisation" of Modern Architecture in the United States" p 247. aesthetically confined modernity - the BeauxArts understanding of "style" as offering multiple exterior options to buildings. It was hence expected that an architect was conversant with, and able to design in, any of several styles, at times dictated by the client's preference. This apparent detachment of style from function, which characterised the American upbringing of Anscombe's architectural youth, can be seen to have resulted in his unashamed draping of buildings in the latest architectural fashions: Neo-Gothic, Elizabethan, Neo-Classical, Arts and Crafts, Art Deco - he did them all, resulting in his architecture being described by Beaven and Stacpoole, for example, as "slick stylism in its extreme form." 28

Anscombe's architectural practice hence developed with a smorgasbord of architectural and historical styles not at odds with early twentieth-century American ideas of progressive architecture and modernity. This context set Anscombe up for a certain architectural versatility whereby architecture equals building-plus-style, and it might be argued that this very sentiment (or perhaps pragmatic business attitude), effecting a

${ }^{28}$ Stacpoole \& Beaven Architecture 1820-1970 p 74. conceptual disconnect of building and style, was one of several factors which enabled architecture for Modernists to become architecture equals building-minus-style. But I suspect that might be another paper.

\section{Modern Industrial Development}

Anscombe had designed his first factory ten years before the 1919 publication of Modern Industrial Development. The factory, at 329 Cumberland St (now 25 Great King Street), was a two-storey brick building for Thomas Scurr a carriage manufacturer. By this stage in the early twentieth century, manufactories had progressed from being housed in castles, churches or monasteries ${ }^{29}$ to those exhibiting respectable classical façades. Jeremy Bentham had advocated for his model of "central observation" for factory design (which was proven too inflexible for technological change in the 1811-13 Panoptican factory at Belper, Derbyshire, demolished 1959), ${ }^{30}$ while later, in 1817, Robert Owen put forward his "Villages of Co-operation." Following this Bournville and Port Sunlight were promoted in the 1880s and 1890s as model industrial villages. The nineteenth century ended with the publication

${ }^{29}$ Darley Factory p 40. 
of Ebenezer Howard's Tomorrow: A Peaceful Path to Real Reform (1898) (republished in 1902 as Garden Cities of Tomorrow), which provided a new context for factory design realised in such buildings as Cecil Hignett's Arts and Crafts Spirella corset factory (1912-21) in Letchworth Garden City; its "harmonious dress and architectural good manners showed that the new model factory could sit down in any company." 31

Such work set the scene for Anscombe's entry into factory design, which co-incided in date, if not in style, with Peter Behren's more famous AEG Turbine Hall, in Berlin (1909). The Scurr carriage factory, which appears, by comparison, rather mundune, prosaic and dull, was brick with a concrete slab and a corrugated iron roof. The ground floor included a Smith's Shop (with plentiful skylighting), a Wood Shop and a Show Room (with Office and Store Room), and anticipated future extension. Upstairs accommodated an attic Storage Space. The façade was characteristically a finer front, with segmental arches capping window and door openings, as distinct from the flat arches which mark the side and rear elevations. A cornice, bracketed

\footnotetext{
${ }^{31}$ Darley Factory p 78.
}

by drain pipes on either side, supported a luke-warm Flemish Revival false-front.

The Scurr factory (1909) was closely followed by Anscombe's 1910-14 J Romison \& Co. confectionary factory at 370 King St (now 378 Great King St), his 1910-11 Wairarapa Farmers' Company freezing works (with AS Mitchell), and his 1916 Mosgiel Co-operative Dairy Factory, as well as numerous warehouses and storage facilities. The reinforced concrete and brick Romison \& Co building accommodated Roasting and Boiling Rooms, Gas Engine and Storage, and Stock and Sales Rooms on the ground floor, with Lozenge, Drying, Machine, Starch, Packing, Deeping and Dining Rooms above. The roof was liberally peppered with skylights in the Machine, Starch and Deeping Rooms. In form it appears as a pseudo saw-tooth roof. A covered passage lined the North elevation, and provided double-door access into the Sales and Boiling Rooms.

None of these buildings, nor Anscombe's industrial warehouses, indicated or anticipated the bravado or intent suggested by his Combination Factory proposal presented in Modern Industrial Development. The 1919 publication followed a presentation to the
Dunedin Manufacturers' Association. ${ }^{32}$ "[T]hose present [he recalled] were so impressed that they asked me to have the matter published in pamphet form." 33 At the meeting, Anscombe presented a Socialist Industrial vision, which he stated "is one which has engaged my attention for the last two and a-half years." 34 His proposal summarised all the the key issues in factory design (productivity, scientific application, working conditions (lighting, heating and ventilation), provision of recreation ("large flat roofs ... for recreation purposes") ${ }^{35}$ modern labour-saving equipment, skeleton construction, and building in reinforced concrete, to ameliorate fire risk and machine vibration). The Combination Factory was an architecturally-dependent business incubator. A large building, potentially funded by shareholders, private subscription, and government subsidies (in recognition of its benefits for returned servicemen), it would be built following the standard set by the modern daylight factory, and provide cooperative-like facilities for small businesses to flourish and grow. A social agenda was

\footnotetext{
32 Anscombe "Housing of Exhibition Visitors" p 3.

33 Anscombe "Housing of Exhibition Visitors" p 3.

${ }^{34}$ Anscombe Modern Industrial Development p 3.

${ }^{35}$ Anscombe Modern Industrial Development $\mathrm{p} 11$.
} 
woven into the architectural model. He encapsulated the Combination Factory Buildings as where:

any number of individual small manufacturers could be accomodated under the most advantageous working conditions, and in which any required amount of floor space could be rented on an extremely attractive basis per square foot, the rent to include power, light, heat, bookkeeping, elevator and janitor service, transport facilities, etc. ${ }^{36}$

In presenting these ideas, Anscombe was not operating in a vaccum and he never suggests he was the originator of these ideas but he was perhaps a synthesiser. The July 1917 New Zealand Institute of Architects Journal of Proceedings had reprinted an excerpt from "Modern Factory Building" The Architect's Builder's Journal which defined three types of factory buildings (Multi-Storey, Weaving Shed and Machine-Shop). ${ }^{37}$ As was common

${ }^{36}$ Anscombe Modern Industrial Development p 7.

37 "Modern Factory Building" pp 96-97. There appear to be minor errors in the transposition of this reference.

This was probably Moritz Kahn's article "Modern factory buildings." This is suggested by the similarities between the NZIAJ article and Kahn's 1917 Design and Construction of Industrial Buildings which are frequently close but not always exact. The content in the NZIAJ article appears to be an amalgamation of chapters III ("Types of Buildings for the Plant") and IX it advocated good natural lighting, standardization (by implication) and the reduction of fire risk. Interestingly it also suggested the key architectural mechanism of movable partitions which would enable the business flexibility that Anscombe's Combined Factory required, one that would be taken up later in the USSR (in theory in Alexander and Leonid Vesnin's third prize scheme for the Palace of Labour (1923), and in practice in Konstantin S. Melnikov's Workers' Clubs). ${ }^{38}$ The NZIAJ article described the elimination of:

solid interior walls ... the space being divided as required by light partitions, carried on the floor slabs, which may be shifted to suit changing needs.

The possibility of change is one that needs to be taken into account in all industrial planning. A prosperous enterprise tends to grow and to require more space for its activities. The original lay-out, therefore, should be planned with a view to the possibility of future

("Architectural Treatment of the Factory Building"). For example: "It is even taken for granted that ugliness in a factory building is inevitable. But there is really no necessity why factories should be ugly" (Kahn Design and Construction of Industrial Buildings $\mathrm{p}$ 47) compares with "They take it for granted that ugliness in a factory is natural and inevitable. But, as a matter of fact, there is no necessity that factories should be ugly" ("Modern Factory Building" p 97).

${ }^{38}$ Berton Moscow pp 211-212. expansion without undue cost of inconvenience. But even with the greatest care in planning, it will often be found that some departments have too much space and others too little, and the structural divisions should not be of such a nature as to make this re-arrangement impossible in case the need for it arises. ${ }^{39}$

The author described the benefit of this mural flexibility as beneficial to the expansion and shrinkage of departments internal to a single business. Anscombe's scheme, in contrast, considered the movable partition as a division between distinct business entities allowing fostered growth which collectively would benefit the wider economy.

Anscombe's first outing of this factory idea was in Dunedin in 1919. His accompanying discussion provided the impetus for the need for the Combination Factory as specific to the post-war climate (to address the needs for growth (via immigration), new industries, increased prosperity, the retraining of returned soldiers, and the building of pragmatic war memorials), ${ }^{40}$ and he validated

39 "Modern Factory Building" pp 96-97; c.f. "The skeleton principle of construction enables dividing partitions to be placed in any desired position, so that the exact floor space can readily be allotted to him." Anscombe Modern Industrial Development p 9.

${ }^{40}$ Anscombe Modern Industrial Development pp 4,6,13,14. 
it with reference to America. ${ }^{41}$ In a later newspaper article (1925), Anscombe was more specific about the architectural precedents for his scheme, mentioning a 1923 visit to the US when he:

inspected several Combined Factory buildings, and in every instance they have proved successful, and have been the means of attracting small manufacturers. In Toledo, Ohio, I was informed that one of the largest manufacturers in that progressive city first commenced business in a combined factory building. in the Indianapolis combined factory, one of the city's largest, manufacturers started in business with 4,400 square feet of floor area, increasing this later to 7,600 square feet. This same firm is now in its own building, with 50,000 square feet of floor area. As there is always a "waiting list," vacant space (if any) is immediately taken up. These combined factories are termed "business incubators," and are mainly for the purpose of providing floor space for small manufacturers. ${ }^{42}$

It was the recurrance of war in 1939 which prompted Anscombe's ressurection of the project in the 1940s, and again he validated the project by referencing America, but rather

${ }^{41}$ He refers positively to "An American authority," "Dr. Prince, an American authority on "The Modern Factory," that "the American manufacturer has recognised the importance of the modern daylight factory," "American Experience," and Americans. Anscombe Modern Industrial Development pp 5,8,9,10,15.

${ }^{42}$ Anscombe "Housing of Exhibition Visitors" p 3. than the Dunedin Manufacturers' Association, or the readers of the Dunedin's Evening Star, Anscombe drew it to the attention of the Prime Minister, Peter Fraser, and the Minister of Industry and Commerce, Dan Sullivan. ${ }^{43}$

Anscombe's initial letter to Sullivan stated its motivation via reference to the tight economic and political context, WWII and an economic need for industrial development. He wrote to alert the Minister to his pending visit to America "primarily to visit both the San Francisco and New York Worlds Fair - but while there I intend to check up on the latest development in Combined Factories, housing, City Planning schemes generally, Air Port Schemes, Bus Termini Stations etc.," ${ }^{44}$ quite an architectural shopping-list for a 66 year-old architect on a wartime soujourn. Anscombe ended the letter asking whether he "can be of any service to your own Department, or that of any other Minister, in which my training as an Architect would be of use, I would look upon it as a privilege to do what I can."45 Simultaneously Anscombe enclosed a copy of his 1919 Modern Industrial Development

\footnotetext{
${ }^{43}$ McCarthy "East meets West" pp 2-9.

${ }^{44}$ Anscombe, letter to D.G. Sullivan. Anscombe's trip

began in June 1940 and concluded in January 1941.

${ }^{45}$ Anscombe, letter to D.G. Sullivan.
}

pamphlet noting that it had:

created a great deal of interest and support at the time, [but it] never materialised. I feel confident though that the Combined Factory idea embodies so many advantages and benefits, it must be adopted in New Zealand some-day. ${ }^{46}$

Following Anscombe's return from America he confirmed with Sullivan that his 1919 pamphlet was still relevant, and he commenced the design of several factories, all of which employed a Modernist aesthetic.

"Libertyland," the R \& WH Symington \& Co. (NZ) Ltd Factory in Palmerston North (1943), for example, was stated to have "a pleasing and dignified appearance [that] might suggest a building housing some cultural or scientific activity." 47 The building was constructed of reinforced concrete (to resist fire and earthquakes), lighting was stressed as important, and it housed rest rooms, a library, a cafeteria and six staff tennis courts. ${ }^{48}$ Modern heating and air-conditioning systems were installed, with the steam boiler ensured "the correct degree of humidity." 49

\footnotetext{
${ }^{46}$ Anscombe, letter to D.G. Sullivan.

47 "Well Planned Factory Building" p 31.

48 "Well Planned Factory Building" p 31.
}

49 "Well Planned Factory Building" p 31. 
Anscombe's Disabled Servicemen's Vocational Training Centre (Wellington, 1943) was also built in reinforced concrete, and its planning resulted from "particular attention ... to the provision of maximum sunshine and natural light and of the healthy conditions obviously desireable in such a building." 50 Its design realised "that health is a first essential to efficiency and accuracy in workmanship." ${ }^{1}$ It included accommodation, two sun-decks, a cafeteria, lounge, reading room, and hobbies room, with "allowance ... made in front of the building for a bowling green." 52

The Disabled Servicemen's Vocational Training Centre also engaged to some extent with ideas of replication, if not massproduction. It was the first disabled servicemen's training centre in the country, and opened on the afternoon of Saturday 18 September 1943 by Prime Minister, Peter Fraser. The report of the opening stated that the building:

was designed for recreational purposes as well as factory activity, and would be duplicated in Auckland,

50 "Wellington's New Vocational Training Centre" p 18.

51 "Well Planned Factory Building" p 31.

52 "Well Planned Factory Building" p 31.
Christchurch and Dunedin. ... It was a building of excellent design. ... The Prime Minister congratulated the architect, Mr. E. Anscombe, the building contractor and workmen on their splendid job. Presentations of an engraved cigarette box to Mr. Moohan by Mr. Murray, and of an ornamental paua shell paper knife to the Prime Minister by Mr. Anscombe were made. ${ }^{53}$

\section{Conclusion: The Art Deco machine}

To relegate the factory to Modernism would be too simple, as would relegating Anscombe's engagement with Modernism as yet another stylistic turn, despite Wigley's refashioning of the movement and its stereotypical white paint in terms of fashion and clothing. ${ }^{54}$ While factory architecture was re-conceived quite literally as a machine, and made strong connections with Modernist aspirations, industrial drives for efficiency and the elimination of waste (nonproductive labour, excessive handling and moving of materials) have also been associated with the ideologies supporting the moderne..$^{55}$

\footnotetext{
53 "Training Centre Opened" p 4.

${ }^{54}$ Wigley White Walls

${ }^{55}$ Lupton and Miller The Bathroom the Kitchen and the Aesthetics of Waste; Cogdell Eugenic Design. References to efficency permeate Anscombe's Modern Industrial Development, for example: "the highest point of efficiency," "Human efficiency," "Low efficiency," "Industrial efficiency," "greater efficiency" Anscombe Modern Industrial Development pp. 3,6-9,11.
}

The factory building, as well as anticipating and embracing the architectures of Modernism, also became the superficial exterior cover of the inner workings of the plant, much the same way that steamlined industrial design would later emphasis the design of the outside in order to hide the inner workings: "The continuous, sculptural forms ... [which sought] to minimize mechnical joints and eliminate visible hinges, bolts, and screws ... enveloping ... [the] consitutent parts inside a continous body."56 Charles Day, author of Industrial Plants asserted that the building "should allow work to go forward as though the building did not exist at all,"57 and factory architecture was increasing considered as the fitting of a building to the production, rather than the housing of the machine within a standard building. ${ }^{58}$ The building, it was said, was frequently "drawn" around the layout and organisation of the machines. ${ }^{59}$

This paper does not conclude then with an elegant or simple or straightforward

\footnotetext{
${ }^{56}$ Lupton and Miller The Bathroom the Kitchen and the Aesthetics of Waste $\mathrm{p} 66$.

${ }^{57}$ Biggs The Rational Factory p 50.

${ }^{58}$ Biggs The Rational Factory p 76.

${ }^{59}$ Biggs The Rational Factory p 76.
} 
categorisation, rather such things collapse inelegantly but possibly productively. Anscombe's 1940s factory designs demonstrate his ability to operate in an architectural idiom of Modernism. While Anscombe has never been straightforwardly or simply an Art Deco designer, his association with Modernism would be, for the purist, something difficult to stomach. Yet if Anscombe was able to convincingly to draw from both the moderne and the Modernist, the functional and industrial origins of Modernism might also, I suggest, be subject to contamination by a moderne association. Anscombe, as an Art Deco-architect-madeModernist through his factory designs, undermines an easy settlement of these two architectural styles and movements as simply distinct and separate. 


\section{REFERENCES}

Anscombe, Edmund "Housing of Exhibition Visitors: An Urgent Question" Evening Star (Saturday 4 April 1925):3.

Anscombe, Edmund, letter to D.G. Sullivan (8 May 1940), private collection, Wellington.

Anscombe, Edmund Modern Industrial Development Dunedin: Evening Star Company Ltd, 1919.

Banham, Reyner A Concrete Atlantis: U.S. Industrial Building and European Modern Architecture 1900-1925 Cambridge, Massachusetts: MIT Press, 1986.

Berton, Kathleen Moscow: An Architectural History London: Cassell \& Collier Macmillian Publishers Ltd, 1977.

Biggs, Lindy The Rational Factory: Architecture, Technology, and Work in America's Age of Mass Production London: Johns Hopkins University Press, 1996.

Cogdell, Christina Eugenic Design: Streamlining America in the 1930s Philadelphia: University of Pennsylvania Press, 2004.

Darley, Gillian Factory London: Reaktion Books Ltd., 2003.

Eggener, Keith, L. "Nationalism, Internationalism and the "Naturalisation" of Modern Architecture in the United States, 19251940" National Identities (September 2006) 8(3):243-258.

Kahn, Moritz The design $\mathcal{E}$ construction of industrial buildings London: Technical Journals, Ltd., 1917.

Kahn, Moritz "Modern factory buildings" Architects' and Builders' Journal (7 March 1917) 45:125-126.

Lupton, Ellen and J. Abbott Miller The Bathroom the Kitchen and the Aesthetics of Waste: A Process of Elimination Cambridge, Massachusetts: MIT List Visual Arts Center, 1992.

McCarthy, C. M. "East meets West: Edmund Anscombe's Combined Factory Building for Aotea Quay, Wellington, New Zealand" The
Design Journal (2002) 5(3):2-9.

McCarthy, Christine "The Making of an Architect: Anscombe in America, 1920-1906" Fabrications: The Journal of the Society of Architectural Historians, Australia and New Zealand (December 2006) 16(2):60-82.

McLeod, Mary "'Architecture of Revolution": Taylorism, Technocracy, and Social Change" Art Journal (Summer 1983) 43(2):132-147.

McLeod, Mary "Le Corbusier, the New Woman, and Domestic Reform [keynote address]" "Progress" SAHANZ conference (Sydney, 3rd October 2003).

"Modern Factory Building" New Zealand Insitute of Architects Journal of Proceedings (July 1917) V(12):96-97.

Price, George The Modern Factory: Safety, Sanitation and Welfare New York: Arno \& the New York Times, 1969; first published NY: Wiley, 1914.

Stacpoole, John and Peter Beaven Architecture 1820-1970 Wellington: A.H. \& A.W. Reed, 1972.

Tann, Jennifer The Development of the Factory London: Cornmarket Press, 1970.

"To Train Disabled Servicemen: New Vocational Centre: GovernorGeneral lays Foundation Stone" Dominion (Tuesday 17 November 1942):4.

Toomath, William "Hidden Persuaders, Forbidden Fruit" "Pleasing homogeneity," "Dull times," and "animated cocktails" New Zealand Architecture in the 1930s: a one day symposium Christine McCarthy (ed) Centre for Building Performance Research, Victoria University, Wellington, New Zealand, 8th December 2006:62-66.

"Training Centre Opened: Disabled Servicemen: Official Ceremony in Wellington" Dominion (Monday 20 September 1943):4.

"Well Planned Factory Building [R \& W.H. Symington \& Co (NZ) Ltd "Libertyland" Palmerston North]" Progress (April 1948):31,33,35. 
"Wellington's New Vocational Training Centre" Home \& Building (Summer 1944) VII(1):18-19.

Wigley, Mark White Walls, Designer Dresses: the Fashioning of Modern Architecture Cambridge, Massachusetts; London, England: The MIT Press, 2001. 